\title{
THE EFFECTS OF AFRICAN CATFISH, CLARIAS GARIEPINUS POND FARM'S EFFLUENT ON WATER QUALITY OF KESANG RIVER IN MALACCA, MALAYSIA
}

\author{
ARIFFIN, F. D. $.^{1,2}-$ HALIM, A. A. ${ }^{1 *}$ - HANAFIAH, M. M. ${ }^{1}-$ AWANG, N. $^{2}-$ OTHMAN, M. $^{2} .^{2}-$ \\ AZMAN, S. A. A. ${ }^{2}-$ BAKRI, N. S. M. ${ }^{2}$ \\ ${ }^{1}$ Centre for Earth Sciences and Environment, Faculty of Science and Technology \\ Universiti Kebangsaan Malaysia, Bangi, Selangor 43600 UKM, Malaysia \\ (phone: +60-3-8921-3002; fax: +60-3-8925-3357) \\ ${ }^{2}$ Environmental Health and Industrial Safety Programme, Faculty of Health Sciences, Universiti \\ Kebangsaan Malaysia, Jalan Raja Muda Abdul Aziz, 50300 Kuala Lumpur, Malaysia \\ (phone: +60-3-9289-7638; fax: +60-3-2692-9032) \\ *Corresponding author \\ e-mail: azharhalim@ukm.edu.my; phone:+60-3-8921-4089; fax: +60-3-8925-3357 \\ (Received $17^{\text {th }}$ Oct 2018; accepted $7^{\text {th }}$ Jan 2019)
}

\begin{abstract}
The aquaculture industry is increasing worldwide. However, many negative impacts have been associated with aquaculture effluent especially in the form of water pollution to the receiving water body. Hence, the aim of this study was to determine the effects of aquaculture effluents mainly from Clarias gariepinus (African Catfish) pond farm on the water quality of Kesang River in Malacca. Three sampling stations were selected at the fish farm. The parameters involved in the monitoring are dissolved oxygen (DO), $\mathrm{pH}$, total dissolved solids (TDS), conductivity, biochemical oxygen demand (BOD), chemical oxygen demand (COD), total suspended solid (TSS), ammonia-nitrogen $\left(\mathrm{NH}_{3}-\mathrm{N}\right)$, nitrite, nitrate, total nitrogen and phosphate. The water quality index was calculated to monitor the quality of the river. Results showed that there were slight effects of aquaculture effluent to the river. It is suggested that the effects of aquaculture effluents are studied according to seasons and the variables are monitored continuously to determine the actual effects of the effluents.
\end{abstract}

Keywords: aquaculture, sharptooth catfish, wastewater, surface water, physicochemical parameters

\section{Introduction}

Aquaculture has been considered as an alternative to assist the world food security issue (Kobayashi et al., 2015) due to the increasing demand for seafood (Nadarajah and Flaaten, 2017). In 2014, the total global aquaculture production was 101.1 million tons, which was valued at US\$ 165.8 billion where Asia dominates this production as much as $88.91 \%$ in volume (Nadarajah and Flaaten, 2017). Malaysia is also promoting aquaculture as an important engine in growing the national economy. Malaysia's aquaculture industry has been developed since 1920's involving three practices, which are freshwater, brackish-water and marine aquaculture (Hamdan et al., 2015).

Aquaculture in Malaysia includes freshwater and marine fishes, aquatic plants, mollusks and crustaceans (Dauda et al., 2018). This industry has increased consistently with the sum production at the end of 2015 was at 506,465.25 tonnes, which valued about RM 3,296,463 (\$US 756,937) (Dauda et al., 2018). In Malaysian production, more than 30 finfish species are farmed, dominated by the African catfish and followed by red (hybrid) tilapia, sea bass, Pangasius sp., and red snapper (Department of Fisheries, 2016). African catfish, Clarias gariepinus is an exotic fish species in Malaysia. It was introduced from Thailand between 1986 and 1989 through aquaculture 
sector (Dauda et al., 2018). This non-native catfish is a fast grower fish, highly disease resistant and favored by the local people (Adan, 2000).

However, there are studies that report the aquaculture industry displays a variety of adverse impacts on the environment such as ecosystem degradation, land erosion, food chain pollution and water pollution (Ottinger et al., 2016). The adverse effects of aquaculture effluents are one of the significant impacts due to lack of enforcement on effluent discharge from aquaculture to the receiving river. According to Cao et al. (2007), effluents discharge without treatment into the receiving water is due to poor management of shrimp and fish farms, thus lead to environmental deterioration.

Rivers are the main source for raw water supply in Malaysia, supplying more than $90 \%$ of the country's water requirements (Hassan et al., 2018). The increasing population and expanding urban areas in Melaka State has caused a gradual rise in demand for water consumption (Daneshmand et al., 2011; Hazmi and Hanafiah, 2018). Melaka State is the third smallest state in Malaysia. Three dams and three reservoirs are the main water resources in Melaka (Tengku Azzlan et al., 2016). The Kesang River and Malacca River provide a total of $80-90 \%$ of the water supply in Melaka. The remaining $10-20 \%$ is imported from the Gerisik River of Johor (Malaysian Water Association, 2008). Kesang River is one of the main raw water supplies in Melaka State. There is a semi-commercial catfish pond farm located nearby the river, where the effluent is directly discharged to the Kesang River. The effluent discharged from fish ponds has a great impact on effective water treatment, which is due to the amount of organic material load, nutrients like nitrogen and phosphorus released to surface water (Teodorowicz, 2013). Water treatment in Malaysia mostly uses conventional water treatments which can only treat raw water that does not violate the National Water Quality Standards (NWQS). Raw water treatment at most water treatment plants is limited to coagulation, sedimentation, filtration and disinfection, which do not include treating the organic materials (Tengku Azzlan et al., 2016).

In 2010, a total of 1,055 water quality monitoring stations were monitored in Malaysia and it was found that $10 \%$ of these stations are polluted (Amneera et al., 2013). The water resource available may not be adequate to supply water to all consumers due to river pollution (Ashraf and Hanafiah, 2018; Harun and Hanafiah, 2018). Therefore, water quality monitoring is vital in Malaysia to identify the existing problem or emerging issues in the future. Monitoring the aquaculture effluents can be a valuable tool for guiding management actions to improve river conditions. Hence, this study was conducted to determine the impact of Clarias gariepinus pond farm effluent on physicochemical parameters of Kesang River in Malacca.

\section{Materials and methods}

\section{Study area}

The study was conducted in Sungai Kesang, Jasin, Malacca which is located in the west coast of Peninsular Malaysia between the latitude of $2^{\circ} 19^{\prime} 45.1^{\prime \prime} \mathrm{N}$ and longitude of $102^{\circ} 23^{\prime} 54.7^{\prime \prime E}$. Kesang River supplies 54 million liters of raw water daily to the state (Tengku Azzlan et al., 2016). The average annual runoff depth is about $500-600 \mathrm{~mm}$ (Shirazi et al., 2013). The length of the Kesang River is about $35 \mathrm{~km}$, running through Jasin Town as a dividing line and a border between the southern states of Malacca and the state of Johor. Kesang River also passes through palm oil plantations. A large proportion of the land near the river is used for growing palm oil trees. Industrialization 
is restricted to around Jasin Town because Kesang River is gazetted as a catchment area. In this study, three sampling stations were selected along the river, first at the river before the farm, the second at the outlet of the farm, and finally is at the river after the farm. The sampling station is shown in Figure 1.

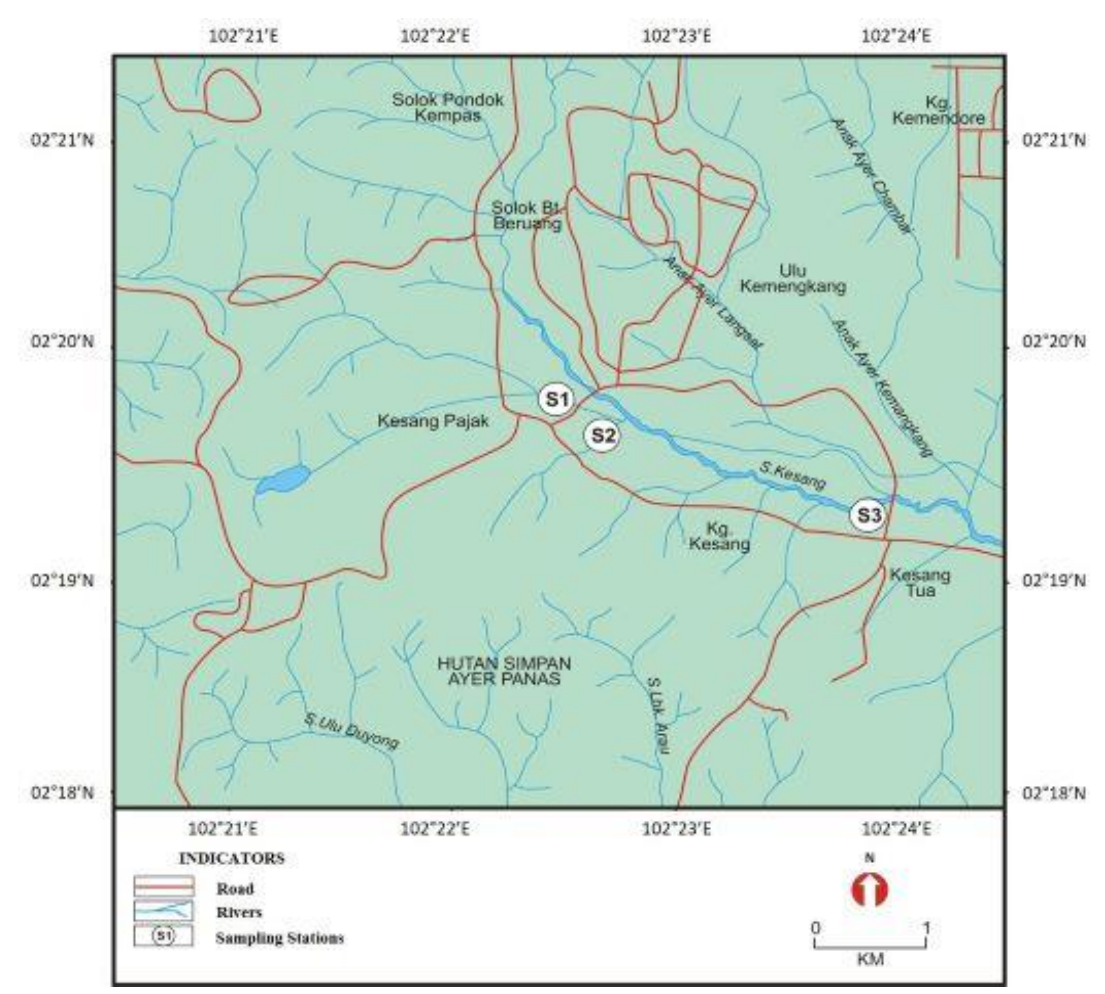

Figure 1. Sampling station map where S1 is Station 1, S2 is Station 2 and S3 is Station 3

\section{Physicochemical analysis}

The data were obtained through sampling and laboratory work. The data obtained were collected six times from December 2017 to June 2018. The selected sampling stations were upstream of the river before the farm (Station 1), catfish pond farm effluent outlet (Station 2) and downstream of the river after the effluent outlet (Station 3 ). The selected water quality parameters used in this study include dissolved oxygen (DO), $\mathrm{pH}$, total dissolved solids (TDS), conductivity, biochemical oxygen demand (BOD), chemical oxygen demand (COD), total suspended solid (TSS), ammonianitrogen $\left(\mathrm{NH}_{3}-\mathrm{N}\right)$, nitrite, nitrate, total nitrogen and phosphate. The WQI formula (Department of Environment, 2011) used to determine of the water quality at Kesang River is as follows (Eq. 1):

$W Q I=0.22 \times S I D O+0.19 \times$ SIBOD $+0.16 \times$ SICOD $+0.15 \times$ SIAN $+0.16 \times$ SISS $+0.12 \times$ SIpH

where WQI is water quality index, SIDO is dissolved oxygen subindex, SIBOD is biological oxygen demand subindex, SICOD is chemical oxygen demand subindex, SIAN is ammonia-nitrogen subindex, SISS is suspended solid subindex, and SIpH is $\mathrm{pH}$ value subindex. WQI classification is illustrated in Table 1. The method used for each parameter is summarized in Table 2. 
The water samples were kept in 1L polyethylene bottles and preserved with $65 \%$ nitric acid until the $\mathrm{pH}$ of the samples reached $\mathrm{pH} 2$. Then, the water samples were kept in $4^{\circ} \mathrm{C}$ until further analysis. The analysis was conducted within 24 hours after sampling.

All data were expressed in average \pm standard deviation. Data were analyzed using Statistical Package for Social Science (SPSS, version 22) software. One-way ANOVA was conducted for comparing water quality parameter at different sampling stations. Tukey's HSD test was conducted for post hoc test. The significant value for the data analyzed was set at $\mathrm{p}<0.05$.

Table 1. WQI classification

\begin{tabular}{c|ll}
\hline Class & & \multicolumn{1}{c}{ Uses } \\
\hline I & - & Conservation of natural environment. \\
& - Water supply I: Practically no treatment required (except \\
& - by disinfection or boiling only). \\
II A & - Fishery I: Very sensitive aquatic species. \\
& - Water supply II - Conventional treatment required. \\
II B & - Rishery II - Sensitive aquatic species. \\
III & - Extensive treatment required. \\
& - Fishery III: common of economic value and tolerant species; livestock drinking. \\
IV & - Irrigation. \\
V & - None of the above. \\
\hline
\end{tabular}

Source: Department of Environment, 2006

Table 2. Methods used for each parameter

\begin{tabular}{|c|c|c|}
\hline Parameters & Methods & Instrument \\
\hline DO & & • $\quad$ YSI Pro DO Meter \\
\hline $\mathrm{pH}$ & & - $\quad$ pH meter HI8424 \\
\hline Temperature & & - $\quad$ pH meter HI8424 \\
\hline Conductivity & & $\begin{array}{l}\text { - } \quad \text { AZ8306 Conductivity / TDS } \\
\text { / Salt meter RS232 }\end{array}$ \\
\hline TDS & & - AZ8306 Conductivity / TDS \\
\hline BOD & BOD5 (APHA 1999) & $\begin{array}{ll} & \text { / Salt meter RS232 } \\
\text { - } & \text { DO Meter (YSI 5000) }\end{array}$ \\
\hline COD & $\begin{array}{l}\text { Method 5220D Closed Reflux Method; } \\
\text { Colorimetric Method (APHA, 1992) }\end{array}$ & $\begin{array}{ll}\text { - } & \text { HACH DR2800 } \\
\text { - } & \text { CODectrophotometer } \\
& \text { CODeactor }\end{array}$ \\
\hline $\mathrm{NH}_{3}-\mathrm{N}$ & Direct Nesslerization (ASTM, 2008) & $\begin{array}{l}\text { - } \quad \text { HACH DR2800 } \\
\text { Spectrophotometer }\end{array}$ \\
\hline TSS & $\begin{array}{l}\text { Photometric method (Krawczyk \& } \\
\text { Gonglewski, 1959) }\end{array}$ & $\begin{array}{ll}\text { - } & \text { HACH DR2800 } \\
\text { Spectrophotometer }\end{array}$ \\
\hline Nitrite & $\begin{array}{l}\text { Diazotization Method (Federal Register, } \\
\text { 1979) }\end{array}$ & $\begin{array}{l}\text { - } \quad \text { HACH DR2800 } \\
\text { Spectrophotometer }\end{array}$ \\
\hline Nitrate & $\begin{array}{l}\text { Method 4500-NO3 Cadmium Reduction } \\
\text { Method (APHA, 1992) }\end{array}$ & $\begin{array}{l}\text { - } \quad \text { HACH DR2800 } \\
\text { Spectrophotometer }\end{array}$ \\
\hline Total Nitrogen & $\begin{array}{l}\text { Method 4500-N Persulfate Method (APHA, } \\
\text { 2005) }\end{array}$ & $\begin{array}{l}\text { - } \quad \text { HACH DR2800 } \\
\text { Spectrophotometer }\end{array}$ \\
\hline Phosphate & $\begin{array}{l}\text { Method 4500-P Ascorbic Acid Method } \\
\text { (APHA, 2005) }\end{array}$ & $\begin{array}{ll}- & \text { COD Reactor } \\
- & \text { HACH DR2800 } \\
& \text { Spectrophotometer }\end{array}$ \\
\hline
\end{tabular}




\section{Results}

All monitored physicochemical parameters were not diverse throughout the whole investigation period at all locations. The mean values of all studied parameters have been compared to the acceptable value of the Recommended Raw Water Quality Criteria which has been developed by the Ministry of Health Malaysia (Ministry of Health Malaysia, 2010). The classifications of water quality according to the Water Quality Index (WQI) were at class III for both river sampling stations, indicating that these stations need to be extensively treated but are suitable for irrigation and agriculture. The results of the study indicated that the effluent from the catfish pond farm have no significant impacts on water quality variations.

As shown in Figure 2a, the range of DO concentrations was from 32.5\% at sampling Station 2 to $75.6 \%$ at sampling Station 1. The Ministry of Health Malaysia (2010) has no specific guide on DO. However, based on the National Water Quality Standards (NWQS) for Malaysia, DO values on sampling Station 1 and 3 are in class II, while DO values at sampling Station 2 is in class IV (EPA, 2008). ANOVA test showed that there was significant difference $(\mathrm{p}<0.05)$ of DO concentrations between sampling stations. A post hoc Tukey's HSD test showed that Stations 1, 2 and 3 differed significantly at $p$ $<0.05$. However, there were no significant difference $(\mathrm{p}>0.05)$ in the mean of DO levels between Station 1 and Station 3.

This study showed that the $\mathrm{pH}$ value ranged from 6.44 at sampling Station 3 to 7.02 at sampling Station 2 as shown in Figure $2 b$. The one-way analysis of variance (ANOVA) test showed that there was no significant difference $(\mathrm{p}>0.05)$ for the $\mathrm{pH}$ values between all the sampling stations.
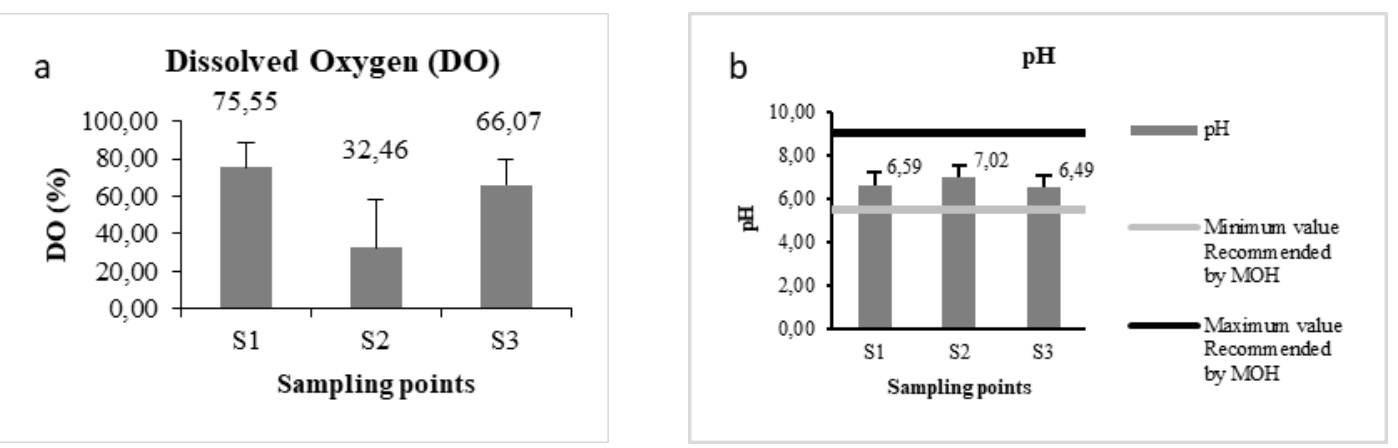

Figure 2. (a) Average of DO concentrations for three sampling stations; $(b) \mathrm{pH}$ values for three sampling stations, where; the upstream before African Catfish pond farm outlet (S1), African Catfish pond farm outlet (S2) and the downstream after African Catfish pond farm outlet (S3) Values in average \pm standard deviation $(n=6)$ Standard from $\mathrm{MOH}$ is not available for $\mathrm{DO}$ parameter

Figure $3 a$ shows the mean value of temperature for all three sampling stations. The range of temperature value was from $27.1^{\circ} \mathrm{C}$ to $28.5^{\circ} \mathrm{C}$. The highest value was recorded at Station 1 and the lowest value was found at Station 2. However, ANOVA test showed that there were no significant differences $(\mathrm{p}>0.05)$ between each sampling station.

The results also showed that conductivity ranged from $87.41 \mu \mathrm{S} / \mathrm{cm}$ to $243.34 \mu \mathrm{S} / \mathrm{cm}$ (Figure $3 b$ ). The lowest value was recorded at Station 1, while the highest value has recorded at Station 2. The conductivity level lies within the acceptable value of the 
Recommended Raw Water Quality Criteria. The ANOVA test showed that there were no significant differences $(\mathrm{p}>0.05)$ between each sampling station.

It was found that TDS values were ranged from $43.84 \mathrm{mg} / \mathrm{L}$ to $121.44 \mathrm{mg} / \mathrm{L}$ as shown in Figure 4a. The highest concentration of TDS was observed at Station 2, while the lowest concentration was obtained at Station 1. All the concentrations were still below the maximum value of the Recommended Raw Water Quality Criteria. The ANOVA test showed that there were no significant differences $(p>0.05)$ between all sampling stations.
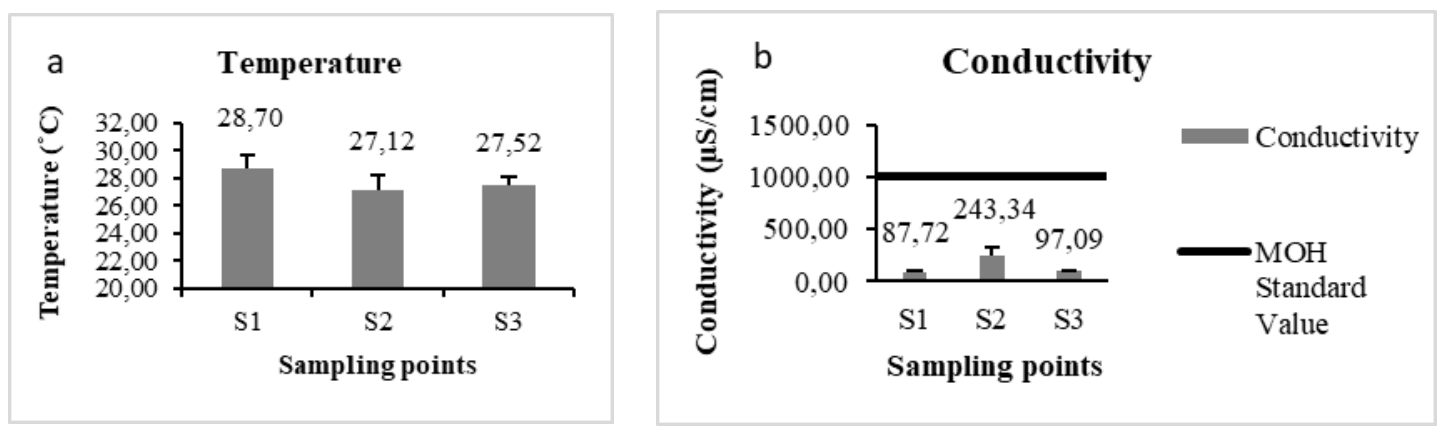

Figure 3. (a) Temperature values for three sampling stations; (b) Conductivity values for three sampling stations, where; the upstream before African Catfish pond farm outlet (S1), African Catfish pond farm outlet (S2) and the downstream after African Catfish pond farm outlet (S3)

Values in average \pm standard deviation $(n=6)$

Standard from $\mathrm{MOH}$ is not available for temperature parameter
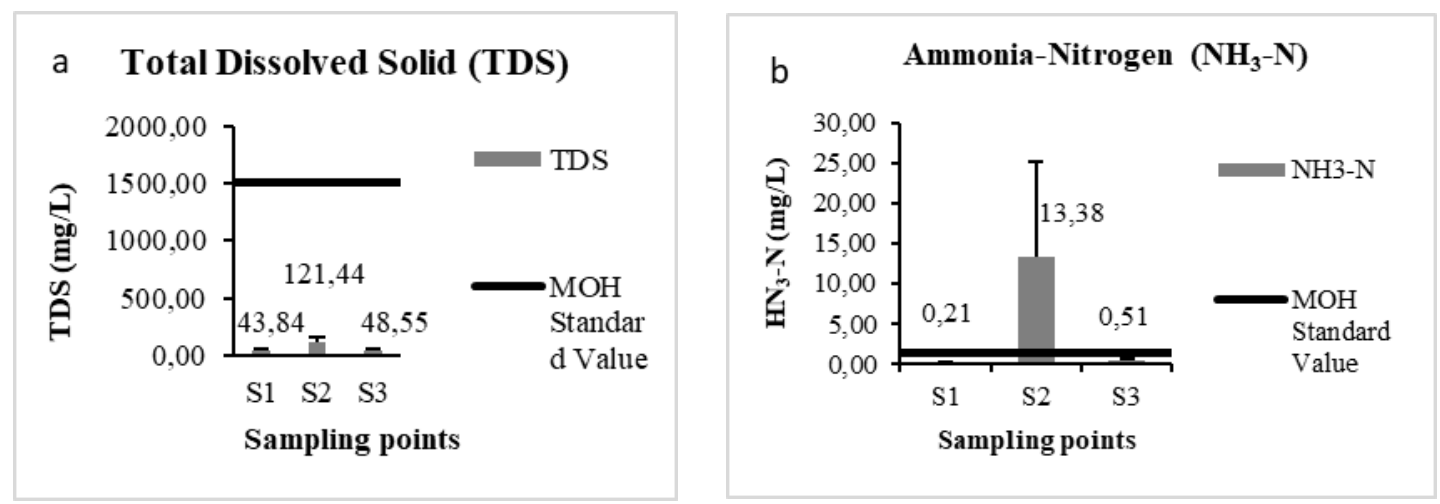

Figure 4. (a) TDS concentrations for three sampling stations; (b) $\mathrm{NH}_{3}-\mathrm{N}$ concentrations for three sampling stations, where; the upstream before African Catfish pond farm outlet (S1), African Catfish pond farm outlet (S2) and the downstream after African Catfish pond farm outlet $(S 3)$, Values in average \pm standard deviation $(n=6)$

The highest ammonia-nitrogen $\left(\mathrm{NH}_{3}-\mathrm{N}\right)$ concentration was observed at $13.38 \mathrm{mg} / \mathrm{L}$ at Station 2. The lowest $\mathrm{NH}_{3}-\mathrm{N}$ concentration was found at $0.32 \mathrm{mg} / \mathrm{L}$ at Station 1 . Figure $4 b$ showed that only Station 2 violates the Recommended Raw Water Quality Criteria acceptable value. The ANOVA test showed there were no significant differences $(p>0.05)$ between each sampling station.

This study also showed that the highest amount of BOD at $39.83 \mathrm{mg} / \mathrm{L}$ was observed at Station 2. The lowest BOD amount at $4.99 \mathrm{mg} / \mathrm{L}$ was recorded at Station 1. ANOVA 
test showed that there was significant difference $(p<0.05)$ of BOD concentrations between sampling stations. A post hoc Tukey's HSD test showed that Stations 1, 2 and 3 differed significantly at $\mathrm{p}<0.05$. Figure $5 a$ showed that only Station 2 had abused the acceptable value of the Recommended Raw Water Quality Criteria. BOD amount at Station 3 was on the border line of the Recommended Raw Water Quality Criteria maximum value.

COD ranged from $91.28 \mathrm{mg} / \mathrm{L}$ to $397.39 \mathrm{mg} / \mathrm{L}$ as shown in Figure $5 b$. The highest level of COD was recorded at Station 2 and the lowest at Station 1. All three sampling stations violated the Recommended Raw Water Quality Criteria acceptable value. ANOVA test showed that there were no significant differences $(p>0.05)$ between each sampling station.
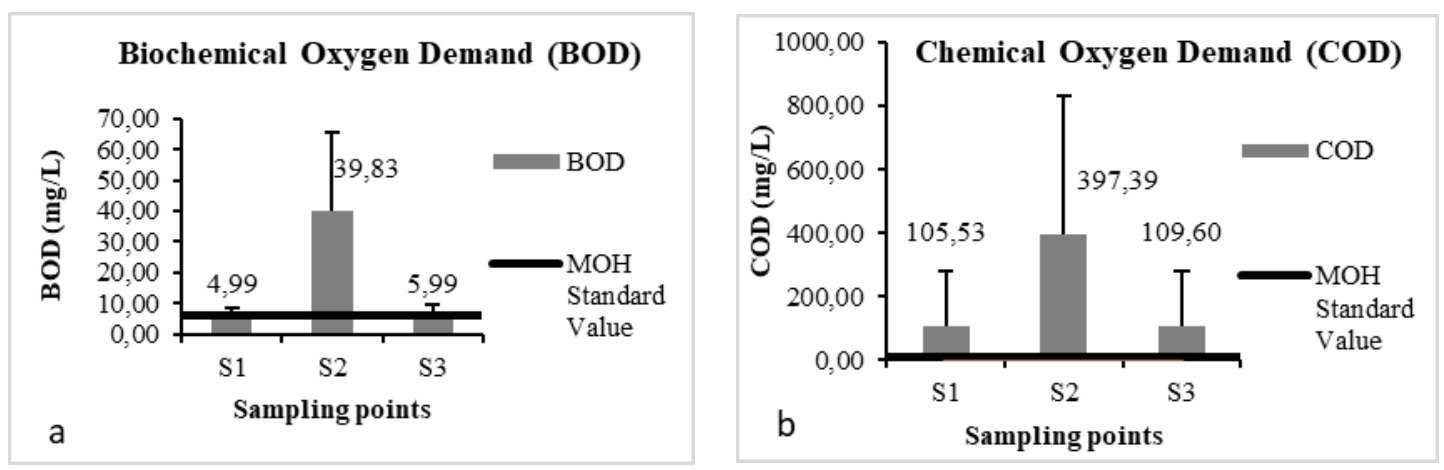

Figure 5. (a) BOD concentrations for three sampling stations; (b) COD concentrations for three sampling stations, where; the upstream before African Catfish pond farm outlet (S1), African Catfish pond farm outlet (S2) and the downstream after African Catfish pond farm outlet $(S 3)$, Values in average \pm standard deviation $(n=6)$

This study observed that the range of TSS were between $37.44 \mathrm{mg} / \mathrm{L}$ to $468.17 \mathrm{mg} / \mathrm{L}$. The highest concentration of TSS was recorded at Station 2, while the lowest concentration was recorded at Station 1 as shown in Figure 6a. Analysis using ANOVA test showed there were no significant differences $(\mathrm{p}>0.05)$ between each sampling station. The Ministry of Health Malaysia (2010) has no specific guideline on TSS.

Figure $6 b$ shows the mean value of phosphate for all three sampling stations. The range of phosphate concentrations were from $0.33 \mathrm{mg} / \mathrm{L}$ to $5.38 \mathrm{mg} / \mathrm{L}$. The highest value was recorded at Station 2 and the lowest value was recorded at Station 1. Station 3 recorded a higher phosphate concentration than Station 1. ANOVA test showed that there was significant difference $(\mathrm{p}<0.05)$ of phosphate concentrations between sampling stations. A post hoc Tukey's HSD test showed that Stations 1, 2 and 3 differed significantly at $\mathrm{p}<0.05$. There is no guideline set by the Ministry of Health Malaysia (2010) on maximum concentration of phosphate as well.

This study showed that the highest nitrite concentration was at $0.24 \mathrm{mg} / \mathrm{L}$ at Station 2. Meanwhile, the lowest concentration of nitrite was at $0.015 \mathrm{mg} / \mathrm{L}$ at Station 1 . There were no significant differences $(\mathrm{p}>0.05)$ between each sampling point based on ANOVA test. As seen in Figure 7a, even though the concentration of nitrite at Station 3 was higher than Station 1, the increase was very minimal. However, there is no guideline set by the Ministry of Health Malaysia (2010) on maximum nitrite concentration. 
Nitrate concentrations ranged from $90.76 \mathrm{mg} / \mathrm{L}$ to $142.89 \mathrm{mg} / \mathrm{L}$. The highest and lowest concentrations have been observed at Station 2 and Station 1, respectively. The concentration of nitrate at Station 3 was slightly increased after passing through the fish pond farm. However, there were no significant differences $(p>0.05)$ between each sampling station using ANOVA test. Figure $7 b$ shows that all three sampling points violated the Recommended Raw Water Quality Criteria acceptable value.
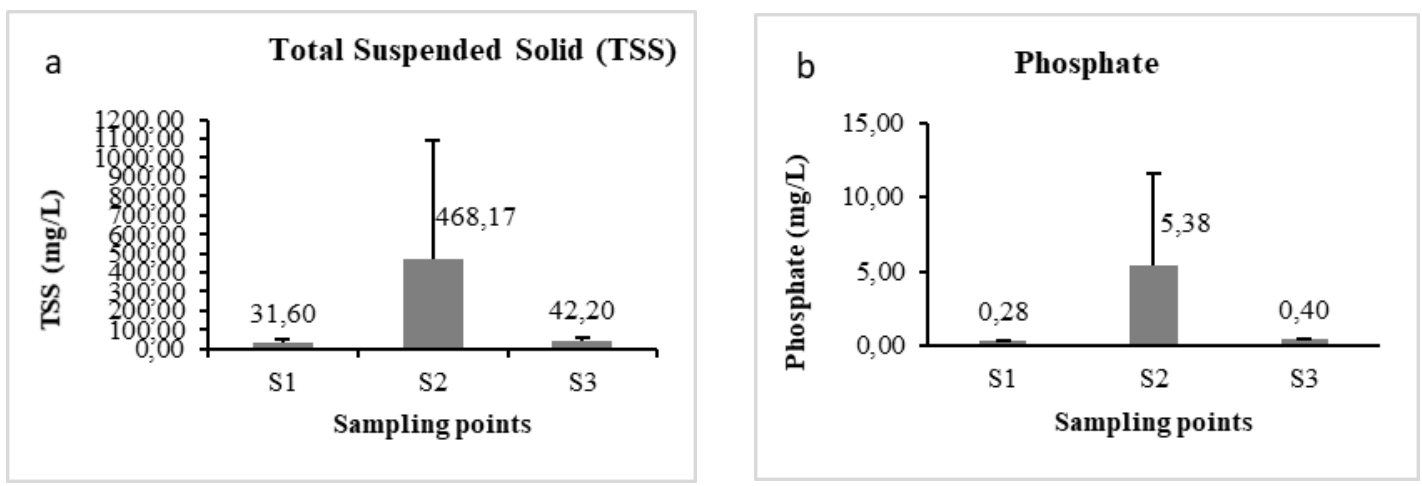

Figure 6. (a) TSS concentrations for three sampling stations; (b) Phosphate concentrations for three sampling stations, where; the upstream before African Catfish pond farm outlet (S1), African Catfish pond farm outlet (S2) and the downstream after African Catfish pond farm outlet (S3), Values in average \pm standard deviation $(n=6)$

Standard from $\mathrm{MOH}$ is not available for TSS and phosphate parameter

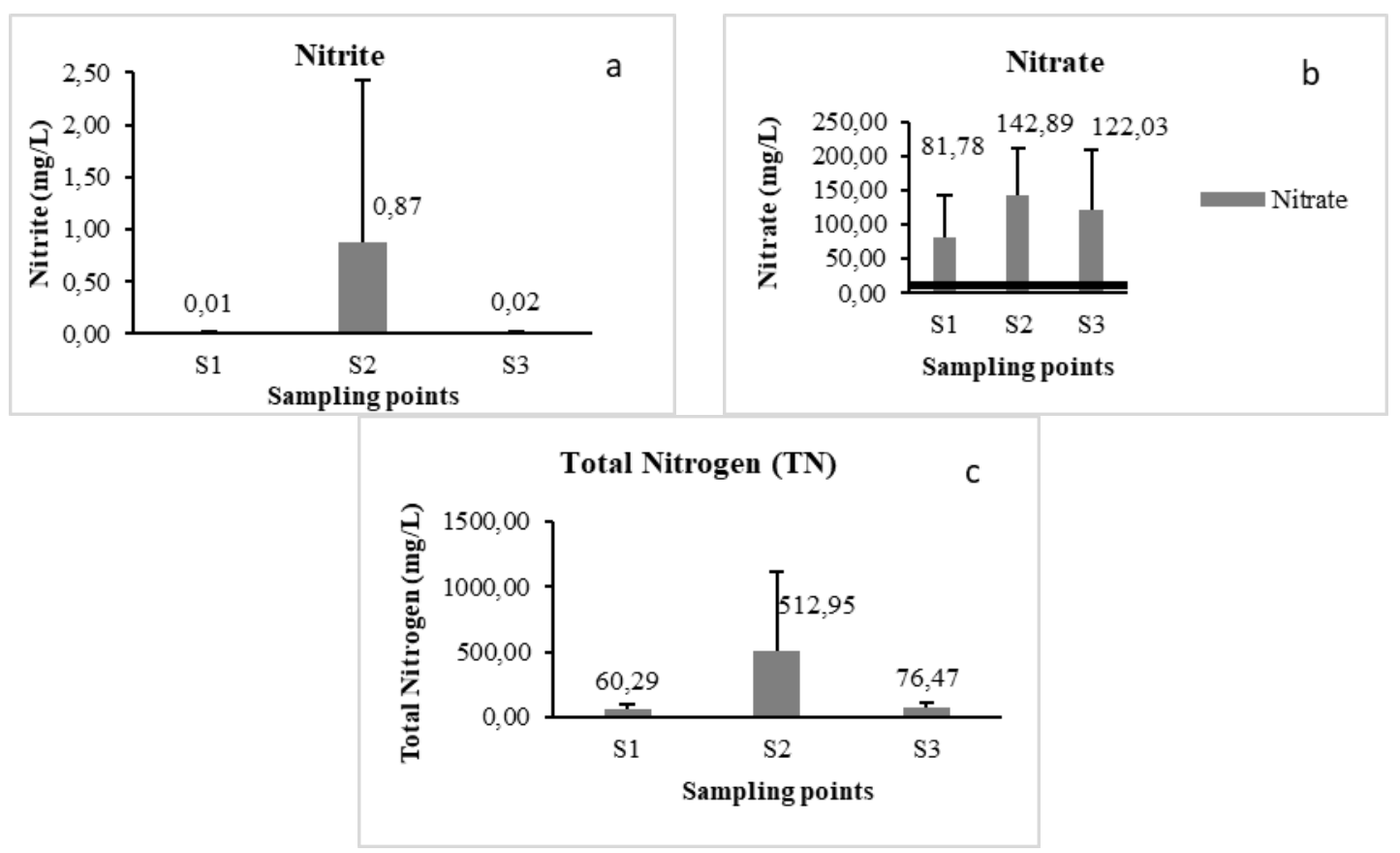

Figure 7. (a) Nitrite concentrations for three sampling stations; (b) Nitrate concentrations for three sampling stations; (c) Total nitrogen concentrations for three sampling stations, where; the upstream before African Catfish pond farm outlet (S1), African Catfish pond farm outlet

(S2) and the downstream after African Catfish pond farm outlet (S3)

Values in average \pm standard deviation $(n=6)$

Standard from $\mathrm{MOH}$ is not available for nitrite and total nitrogen parameter 
This study showed that the highest concentration of total nitrogen was at 512.95 $\mathrm{mg} / \mathrm{L}$ at Station 2, while the lowest concentration at $60.29 \mathrm{mg} / \mathrm{L}$ at Station 1 as shown in Figure $7 c$. ANOVA test showed that there was significant difference $(\mathrm{p}<0.05)$ of phosphate concentrations between sampling stations. A post hoc Tukey's HSD test showed that all sampling stations differed significantly at $\mathrm{p}<0.05$. There is no guideline set by the Ministry of Health Malaysia (2010) on maximum concentration of total nitrogen.

The WQI calculation of the water classification for Station 1 and Station 3 were reported to be in Class III. Class III is defined as moderately polluted where the water needs to be treated extensively.

\section{Discussion}

Dissolved oxygen (DO) is of uttermost importance in water quality, because it is essential for aerobic respiration (Boyde, 2015). Low DO concentrations at sampling Station 2 was due to the presence of high organic materials resulting from overfeeding of fish (US Environmental Protection Agency, 1974). DO concentration at sampling Station 3 was lower Station 1 due to the release of organic and inorganic pollutants as of biological matters from Station 2. However, the result of this research showed that the pollutants released from the fish farm had slightly decreased the DO levels of water that passed through it.

The $\mathrm{pH}$ of aquatic systems is an important criterion of the water quality in the watershed areas (Yisa and Jimoh, 2010). The value is used to determine the level of alkalinity or acidity of water (Hanafiah et al., 2018). The results were within the $\mathrm{pH}$ range of the Recommended Raw Water Quality Criteria (Ministry of Health Malaysia, 2010). The results in this study were in agreement to the study conducted by Teodorowicz (2013) where $\mathrm{pH}$ value had dropped after the water passed through the studied catfish pond farm. It was reported that the $\mathrm{pH}$ decreased due to the increase of feeding fish respiration rates, which increased the content of free $\mathrm{CO}_{2}$. However, the $\mathrm{pH}$ values were still in the normal range of natural water $\mathrm{pH}$ that is $6-9$ (Boyde, 2015) and is considered safe to aquatic organism (Teodorowicz, 2013). The extreme values of $\mathrm{pH}$ can cause destruction to the sensitive aquatic organism (Hassan et al., 2018).

The temperature of river water is an important characteristic for aquatic system because it could affect dissolved oxygen levels, species composition, chemical and biological activities (Shuhaimi-Othman et al., 2007; Hanafiah et al., 2018). This study showed that the temperature at the upstream sampling point is higher than downstream sampling point. This was not in line with the study conducted by Al-Badaii et al. (2013) in which the study found that temperature values increased from upstream to downstream. The concentrations of temperature recorded in this study were approximately comparable to the study reported for Malacca River (range $26^{\circ} \mathrm{C}-32^{\circ} \mathrm{C}$ ) by Hua (2017). In general, weather conditions, sampling time and location are the factors that could give impact on the increase or reduction of temperature values (AlBadaii et al., 2013). The weather conditions during the sampling time is shown in Table 3.

Conductivity is a substance's capability to carry an electrical current (Boyde, 2015). Conductivity in water was conveyed by inorganic dissolved solids such as calcium, chloride, aluminum cations, nitrate, sulfate, iron, magnesium and sodium (Al-Badaii, 2011; Boyde, 2015). It is also influenced by temperature and organic compounds such 
as oil, alcohol, phenol and sugar (Al-Badaii, 2011). According to Al-Badaii et al. (2013) and Laila et al. (2018), most freshwater conductivity ranges from 10 to $1000 \mu \mathrm{S} / \mathrm{cm}$. Kesang River showed that the level of conductivity was lower than the study conducted in Malacca River (Hua, 2017) where the conductivity levels had ranged from 109.60 $\mu \mathrm{S} / \mathrm{cm}$ to $1950.72 \mu \mathrm{S} / \mathrm{cm}$. Harun et al. (2010) stated that the conductivity level in the water that receives pollution can exceed $1000 \mu \mathrm{S} / \mathrm{cm}$.

Table 3. Weather conditions during the sampling time

\begin{tabular}{c|c|c}
\hline Sampling months & Rainfal (mm) & Temperature $\left({ }^{\circ} \mathbf{C}\right)$ \\
\hline December 2017 & 0.0 & 26.4 \\
January 2018 & 22.9 & 26.5 \\
February 2018 & 0.0 & 28.0 \\
March 2018 & 0.2 & 25.9 \\
May 2018 & 0.0 & 28.5 \\
June 2018 & 4.1 & 25.9 \\
\hline
\end{tabular}

Source: Meteorology Department of Malaysia, 2018

Dissolved solids are tiny particles considered to be in true solution. Dissolved solids contain largely inorganic and some organic compounds (Boyde, 2015). A slight increase of TDS concentration was observed in Station 3 after the water had passed through the fish pond farm. TDS concentration in the river was due to the human activities along the river and suspended matter from overflow water (Al-Badaii et al., 2013). The TDS concentrations in Kesang River were much lower compared to TDS level observed in Malacca River (Hua, 2017) where the study reported that the TDS had ranged from $77.22 \mathrm{mg} / \mathrm{L}$ to $10444.61 \mathrm{mg} / \mathrm{L}$. TDS concentration of less than $1000 \mathrm{mg} / \mathrm{L}$ in water can be used for drinking and irrigation (Oyem et al., 2014).

The presence of ammonia is due to the presence of decomposing urea, feces and organic matter since that is the initial product of the decomposition of nitrogenous organic wastes and respiration (Zweig, 1999). High $\mathrm{NH}_{3}-\mathrm{N}$ concentration can be toxic to aquatic organisms, but it could provide nutrients for growth of algae in small quantities (Corwin et al., 1999). However, the ammonia toxicity is influenced by the increase in temperature, $\mathrm{pH}$ and decrease of DO (Zweig, 1999).

Biochemical oxygen demand (BOD) concentrations show the amount of dissolved oxygen used for the decomposition of organic matter by microorganisms (Boyd and Tucker, 2014). Typical BOD amount at pond aquaculture effluent is $10-30 \mathrm{mg} / \mathrm{L}$ (Suratman et al., 2015). BOD amount at Station 2 slightly exceeded the typical amount of BOD at pond aquaculture effluents. This is because there are many organic materials that can be broken down by microorganisms and this process requires dissolved oxygen (Asman et al., 2017). The sources of the organic matters are fertilizer, animal farm waste and septic system (Al-Badaii et al., 2013).

Chemical oxygen demand (COD) is the amount of dissolved oxygen required by the oxidizing agent of all the organic matter found in the body of water that produces $\mathrm{CO}_{2}$ and ammonia as a product (Din et al., 2012). COD readings will be compared directly with the BOD reading to distinguish between the value of oxidized material in terms of biological and chemical oxidizing substances (Suratman et al., 2005). Usually, COD reading value is higher than BOD value. This is because it will go through the oxidation process and almost all organic matter will be oxidized (Vesilind et al., 1988). The concentration of COD in unpolluted water is usually less than $20 \mathrm{mg} / \mathrm{L}$ (Hassan et al., 
2018). Thus, the high level of COD indicates the high level of water pollution in the study area (Waziri and Ogugbuaja, 2010) where there were occurrences of organic and inorganic matter oxidation (Hassan et al., 2018).

Total suspended solid (TSS) is defined as the total amount of organic and inorganic particles scattered in water (United States Environmental Protection Agency, 2003). According to Rosli et al. (2010), TSS level of less than $30.0 \mathrm{mg} / \mathrm{L}$ was considered low and TSS level of more than $50.0 \mathrm{mg} / \mathrm{L}$ was considered high value. The Department of Environment, Malaysia (2006) sets the maximum value of TSS in rivers as $150 \mathrm{mg} / \mathrm{L}$. The river sampling points in this study did not violate the guideline set by Department of Environment (2006). High suspended solids concentrations can lower water quality by absorbing light and increasing the water temperature, making the ability of the water to hold oxygen needed for aquatic life to be reduced (Vesilind et al., 1988). TSS was also linked to nutrients, metals and chemicals transported by the river from anthropogenic activities (Rosli et al., 2010).

Phosphate in aquaculture effluents was continuously supplied by the decomposition of uneaten feed and feces (Boyd, 1998; Jegatheesan et al., 2011). Lin et al. (2002) reported that the range of phosphate concentrations in aquaculture effluent were 3.1 $\mathrm{mg} / \mathrm{L}-17.7 \mathrm{mg} / \mathrm{L}$. The phosphate concentration at Station 2 was in line with the study reported by Lin et al. (2002). The high level of phosphate in water body is associated with the occurrence of eutrophication (WHO, 1998).

Nitrite is formed through a nitrification process primarily as an intermediary in converting ammonia to nitrate (Zweig, 1999). According to Boyd (2015) and Zweig (1999), high concentration of nitrite is uncommon in aquatic system because nitrite is quickly oxidized to nitrate. Usually, the presence of nitrite is below $0.05 \mathrm{mg} / \mathrm{L}$ in oxygenated water. However, the nitrite concentration at Station 2 was above $0.05 \mathrm{mg} / \mathrm{L}$ which might be due to low DO concentration (Boyd, 2015). Nitrite is toxic to aquatic animals when the concentration reaches $1 \mathrm{mg} / \mathrm{L}$ and above.

Nitrate is the final oxidation product of nitrogen which is very mobile in water (AlBadaii et al., 2013; Hassan et al., 2018). Nitrate is much less toxic than other major inorganic nitrogen compounds (Zweig, 1999). However, nitrate concentration of 50 $\mathrm{mg} / \mathrm{L}$ and above in ground and drinking water is considered as Nitrate Vulnerable Zone (Giammarino and Quatto, 2015). High concentration of nitrate in river water is potentially harmful to human and animal health. According to Ling et al. (2007), aquaculture is the main contributor of ecosystem pollution due to the discharging of aquaculture waste into the receiving water. The high concentration of nutrients in a fish pond farm is due to the accumulation of feed residue and fish excreta (Lin et al., 2002).

Total nitrogen is a combination of ammonia, ammonium, nitrite and nitrate (Boyd, 2015; Chen and Kang, 2016). Nitrogen can be found majorly as organic matter in bottom sediments, but small amounts of nitrogen can be found in the water to include nitrogen gas, nitrate, nitrite, ammonia, and nitrogen in dissolved and particulate organic matter (Boyd, 2015). The concentration of total nitrogen at Station 3 was slightly higher than Station 1. Jegatheesan et al. (2011) reported that 22\% nitrogen still remains in the water of the catfish pond. About $7 \%-32 \%$ of total nitrogen in the water was carried by suspended solid (Turcios and Papenbrock, 2014). Generally, the high concentration of nitrogen in rivers is due to the use of nitrogen-containing fertilizers, animal waste, septic system, industrial processes, atmospheric deposition from nitrogen oxide emission, irrigation and storm runoffs from farmlands which can affect the drinking water quality and aquatic ecosystem (Liu et al., 2018). 


\section{Conclusion}

In conclusion, we found the physicochemical characteristics of African Catfish, Clarias gariepinus pond farm's effluent affect the quality of water for certain parameters such as COD and nitrate that exceed the permissible limit of the Recommended Raw Water Quality Criteria. High concentration of COD and nitrate need to be further treated to reduce the accumulation of the pollutants to the receiving water body. Some parameters such as nitrate cannot be treated by conventional treatments. So, high concentration of nitrate could have an impact on human health if not treated properly. A regular monitoring is vital to determine the effects of catfish pond farm effluents to river.

Acknowledgements. The researchers wish to extend their appreciation to Universiti Kebangsaan Malaysia for funding this research through a research grant GUP-2017-044 and researchers also would like to express their gratitude to Malacca Water Regulatory Board (Badan Kawal Selia Air Melaka) for partial funding of this study.

\section{REFERENCES}

[1] Adan, R. I. Y. (2000): Catfish culture in Southeast Asia. - SEAFDEC Asian Aquaculture 22: 16-17.

[2] Al-Badaii, F. M. (2011): Water Quality Assessment of the Semenyih River. - [M.S. thesis] Universiti Kebangsaan Malaysia, Selangor, Malaysia.

[3] Al-Badaii, F., Shuhaimi-Othman, M., Gasim, M. B. (2013): Water quality assessment of the Semenyih River, Selangor Malaysia. - Journal of Chemistry 2013: 871056.

[4] Amneera, W. A., Nor Wahidatul Azura Zainon Najib, Siti Rawdhoh Mohd Yusof, Ragunathan, S. (2013): Water Quality Index of Perlis River, Malaysia. - International Journal of Civil \& Environmental Engineering IJCEE-IJENS 13(2): 1-6.

[5] APHA. (1992): Standard Methods for the Examination of Water and Wastewater. 18th Edition. - American Public Health Association (APHA), American Water Works Association (AWWA) and Water Pollution Control Federation (WPCF), Washington DC.

[6] APHA. (1999): Standard Methods for the Examination of Water and Wastewater. 20th Edition. - American Public Health Association, Washington DC.

[7] APHA. (2005): Standard Methods for the Examination of Water and Wastewater. 21st Edition. - American Public Health Association (APHA), American Water Works Association (AWWA) and Water Environment Federation, Washington DC.

[8] Ashraf, M. A., Mohd Hanafiah, M. (2018): Sustaining life on earth system through clean air, pure water, and fertile soil. - Environmental Science Pollution Research. https://doi.org/10.1007/s11356-018-3528-3.

[9] Asman, N. S., Halim, A. A., Hanafiah, M. M., Ariffin, F. D. (2017): Determination of Rainwater Quality from Rainwater Harvesting System at Ungku Omar College, UKM Bangi. - Sains Malaysiana 46(8): 1211-1219.

[10] ASTM D1426-08. (2008): Standard Test Methods for Ammonia Nitrogen in Water. ASTM International, West Conshohocken, PA.

[11] Boyd, C. E. (1998): Water Quality for Pond Aquaculture. - Auburn University, International Center for Aquaculture and Aquatic Environments, Alabama.

[12] Boyd, C. E. (2015): Water Quality: An Introduction. - Springer, Switzerland.

[13] Boyd, C. E., Tucker, C. S. (2014): Handbook for Aquaculture Water Quality. Craftmaster, Auburn. 
[14] Cao, L., Wang, W., Yang, Y., Yang, C., Yuan, Z., Xiong, S., Diana, J. (2007): Environmental Impact of Aquaculture and Countermeasures to Aquaculture Pollution in China. - Environmental Science and Pollution Research 14: 452-462.

[15] Chen, C. F., Kang, S. F. (2016): Effects of Substrates and Plant Species on Water Quality of Extensive Green Roofs. - Applied Ecology and Environmental Research 14(2): 77-91.

[16] Corwin, D. L., Loague, K., Ellsworth, T. R. (1999): Advanced Information Technologies for Assessing Nonpoint Source Pollution in the Vadose Zone: Conference Overview. Journal of Environmental Quality 28(2): 357-365.

[17] Daneshmand, S., Huat, B. B. K., Hossein, M., Thamer, A. M. A. (2011): Study on Water Quality Parameters of Linggi and Melaka Rivers Catchments in Malaysia. - Engineering Journal 15: 41-52.

[18] Dauda, A. B., Natrah, I., Karim, M., Kamarudin, M. S., Bichi, A. H. (2018): African Catfish Aquaculture in Malaysia and Nigeria: Status, Trends and Prospects. - Fisheries and Aquaculture Journal 9: 237-241.

[19] Department of Environment (2006): Water Quality Index. - Department of Environment, Ministry of Science, Technology and Environment Malaysia, Kuala Lumpur.

[20] Department of Environment (2011): Malaysia Environmental Quality Report. Department of Environment, Ministry of Science, Technology and Environment Malaysia.

[21] Department of Fisheries (2016): Annual Fisheries Statistics 2015. - Department of Fisheries, Malaysia, Ministry of Agriculture and Agro-based Industries, Putrajaya.

[22] Din, H. M., Toriman, M. E., Mokhtar. M., Elfithri, R., Aziz, N. A. A., Abdullah, N. M., Kamarudin, M. K. A. (2012): Kepekatan Beban Bahan Pencemar di Alur Ilmu Kampus UKM Bangi: Kaedah Min Kepekatan Peristiwa (EMC). - The Malaysian Journal of Analytical Sciences 16(3): 353-365.

[23] EPA. (2008): National Water Quality Standards for Malaysia. - www.wepadb.net/policies/law/malaysia/eq_surface.htm\#. Accessed on 2 July 2018.

[24] Federal Register. (1979): Diazotization Method. - Federal Register 44(85): 25505. Federal Register, Pittsburgh, PA.

[25] Giammarino, M., Quatto, P. (2015): Nitrates in Drinking Water: Relation with Intensive Livestock Production. - Journal of Preventive Medicine and Hygiene 56: 187-189.

[26] Hamdan, R., Othman, A., Kari, F. (2015): Climate Change Effects on Aquaculture Production Performance in Malaysia: An Environmental Performance Analysis. International Journal of Business and Society 16: 364-385.

[27] Hanafiah, M. M., Hashim, N. A., Ahmed, S. T., Ashraf, M. A. (2018a): Removal of chromium from aquesous solutions using a palm kernel shell adsorbent. - Desalination and Water Treatment 118: 172-180.

[28] Hanafiah, M. M., Yussof, M. K. M., Hasan, M., Abdulhasan, M. J., Toriman, M. E. (2018b): Water Quality Assessment of Tekala River, Selangor, Malaysia. - Applied Ecology and Environmental Research 16(4): 5157-5174.

[29] Harun, S., Abdullah, M. H., Mohamed, M., Fikri, A. H., Jimmy, E. O. (2010): Water Quality Study of Four Streams within Maliau Basin Conservation Area, Sabah, Malaysia. - Journal of Tropical Biology \& Conservation 6: 109-113.

[30] Harun, S. N., Hanafiah, M. M. (2018): Estimating the country-level water consumption footprint of selected crop production. - Applied Ecology and Environmental Research 16(5): 5381-5403.

[31] Hassan, M. A. A., Gasim, M. B., Hanafiah, M. M., Elhadi, R. A. A., Azman, A. (2018): GIS-Based Analysis of Water Quality Deterioration in the Nerus River, Kuala Terengganu, Malaysia. - Desalination and Water Treatment 112: 334-343.

[32] Hazmi, N. I. A., Hanafiah, M. M. (2018): Phytoremediation of livestock wastewater using Azolla filiculoides and Lemna minor. - Environment \& Ecosystem Science 2(1): 13-16.

[33] Hua, A. K. (2017): Identifying the Source of Pollutants in Malacca River Using GIS Approach. - Applied Ecology and Environmental Research 15(4): 571-588. 
[34] Jegatheesan, V., Shu, L., Visvanathan, C. (2011): Aquaculture Effluent: Impacts and Remedies for Protecting the Environment and Human Health. - Encyclopedia of Environmental Health: 123-135.

[35] Kobayashi, M., Msangi, S., Batka, M., Vannuccini, S., Dey, M. M., Anderson, J. L. (2015): Fish to 2030: The Role and Opportunity for Aquaculture. - Aquaculture Economics \& Management 19: 282-300.

[36] Krawczyk, D., Gonglewski, N. (1959): Determining Suspended Solids Using a Spectrophotometer. - Sewage and Industrial Wastes 31(10): 1159-1164.

[37] Laila, O. M. A., Gasim, M. B., Toriman, M. E., Hassan, M. A. A. (2018): The Assessment of Physico-Chemical and Biological Water Quality Characteristics of the Ibai River between Wet and Dry Seasons, Kuala Terengganu, Malaysia. - Journal of Fundamental and Applied Sciences 10(1S): 396-411.

[38] Lin, Y. F., Jing, S. R., Lee, D. Y., Wang, T. W. (2002): Nutrient Removal from Aquaculture Wastewater Using a Constructed Wetlands System. - Aquaculture 209: 169184.

[39] Ling, C., Weimin, W., Yi, Y., Yang, C., Yuan, Z., Xiong, S., Diana, J. (2007): Environmental Impact of Aquaculture and Countermeasures to Aquaculture Pollution in China. - Environmental Science and Pollution Research 14: 452-462.

[40] Liu, H., Chen, Z., Guan, Y., Xu, S. (2018): Role and Application of Iron in Water Treatment for Nitrogen Removal: A Review. - Chemosphere 204: 51-62.

[41] Malaysian Water Association. (2008): 50th year Achievement in Water Industry. Melaka, Issue no 15.

[42] Meteorology Department of Malaysia. (2018): Meteorology Data for Year 2017 and 2018. - National Climate Centre, Petaling Jaya.

[43] Ministry of Health Malaysia. (2010): Recommended Raw Water Quality. http://kmam.moh.gov.my/public-user/drinking-water-quality-standard.html. Accessed on 2 July 2018.

[44] Nadarajah, S., Flaaten, O. (2017): Global Aquaculture Growth and Institutional Quality. Marine Policy 84: 142-151.

[45] Ottinger, M., Clauss, K., Kuenzer, C. (2016): Aquaculture: Relevance, Distribution, Impacts and Spatial Assessments: A review. - Ocean \& Coastal Management 119: 244266.

[46] Oyem, H. H., Oyem, I. M., Ezeweali, D. (2014): Temperature, pH, Electrical Conductivity, Total Dissolved Solids and Chemical Oxygen Demand of Groundwater in Boji-Bojiagbor/ Owa Area and Immediate Suburbs. - Research Journal of Environmental Sciences 8(8): 444-450.

[47] Rosli, N., Gandaseca, S., Ismail, J., Jailan, M. I. (2010): Comparative Study of Water Quality at Different Peat Swamp Forest of Batang Igan, Sibu Sarawak. - American Journal of Environmental Sciences 6(5): 416-421.

[48] Shirazi, S. M., Imran, H. M., Akib, S., Zulkifli, Y., Harun, Z. B. (2013): Groundwater Vulnerability Assessment in the Melaka State of Malaysia Using DRASTIC and GIS Techniques. - Environmental Earth Sciences 70: 2293-2304.

[49] Shuhaimi-Othman, M., Lim, E. C., Mushrifah, I. (2007): Water Quality Changes in Chini Lake, Pahang, West Malaysia. - Environmental Monitoring and Assessment 131(1-3): 279-292.

[50] Suratman, S., Ali, A., Ting, L. T. (2005): Penilaian Indeks Kualiti Air di Lembangan Sungai Ibai, Terengganu. - Sains Malaysiana 34(2): 55-59.

[51] Suratman, S., Sailan, M. I. M., Hee, Y. Y., Bedurus, E. A., Latif, M. T. (2015): A Preliminary Study of Water Quality Index in Terengganu River Basin, Malaysia. - Sains Malaysiana 44(1): 67-73.

[52] Tengku Azzlan, T. A. F., Chew, B. C., Lau, K. L. (2016): Sustainable Water Management for Water Supply Efficiency: A Case Study at Syarikat Air Melaka Berhad. - Journal of Technology Management and Business 3: 1-21. 
[53] Teodorowicz, M. (2013): Surface Water Quality and Intensive Fish Culture. - Archives of Polish Fisheries 21: 65-111.

[54] Turcios, A. E., Papenbrock, J. (2014): Sustainable Treatment of Aquaculture Effluents What Can We Learn from the Past for the Future? - Sustainability 6: 836-856.

[55] United States Environmental Protection Agency. (2003): Developing Water Quality Criteria for Suspended and Bedded Sediments (SABs); Potential Approaches. http://www.epa.gov/wqc/developing-water-quality-criteria-suspended-andbeddedsediments-sabs-potential-approaches. Accessed on 5 July 2018.

[56] US Environmental Protection Agency. (1974): Pollution Aspects of Catfish Production: Review and Projection. - Environmental Protection Technology Series, Washington.

[57] Vesilind, P. A., Peirce, J. J., Weiner, R. (1988): Environmental Engineering. 2nd Ed. Butterworth-Heinemann, Stoneham, MA.

[58] Waziri, M., Ogugbuaja, V. O. (2010): Interrelationship between Physicochemical Water Pollution Indicators: A Case Study of River Yobe-Nigeria. - American Journal of Scientific and Industrial Research 1: 76-80.

[59] WHO. (1998): Guidelines for Drinking Water Quality. 2nd Ed. - WHO, Geneva.

[60] Yisa, J., Jimoh, T. (2010): Analytical Studies on Water Quality Index of River Landzu. American Journal of Applied Sciences 7: 453-458.

[61] Zweig, R. D. (1999): Source Water Quality for Aquaculture: A Guide for Assessment. World Bank, California. 